\title{
Genetic Architecture of Yield Components Accessed Through Line $\times$ Tester Analysis in Wheat (Triticum Aestivum L.)
}

\author{
Rasheda Aslam ${ }^{1, *}$, Muneeb Munawar ${ }^{1}$, Abdus Salam ${ }^{2}$ \\ ${ }^{1}$ Ayub Agricultural Research Institute, Pakistan \\ ${ }^{2}$ University of Agriculture, Faisalabad, Pakistan \\ *Corresponding Author: rashida291@gmail.com
}

Copyright (C) 2014Horizon Research Publishing all rights reserved

\begin{abstract}
Line $\times$ tester analysis is one of breeding strategy to evaluate combining ability effects of genotypes and also to provide information regarding genetic mechanisms controlling certain traits. Three elite wheat lines were used as female parents viz. 9436, 9444 and 9452 and three wheat varieties viz. SH-2002, Sehar 2006 and Lasani 2008 as male parents to produce $9 \mathrm{~F} 1$ crosses. Parent line 9452 and tester SH-2002 were found good general combiner for yield and its components which are important in grain yield improvement. $9436 \times \mathrm{SH}-2002$, 9444× SH-2002, 9452 $\times$ Sehar 2006 and $9452 \times$ Lasani 2008 were more promising hybrids for grain yield components. The combining ability studies indicate the existence of both additive and non-additive gene effects in genetic material. Thus selection should be practiced either for hybrid breeding or pure line wheat varieties after achieving desired homozygosity in succeeding generations $\left(\mathrm{F}_{5-} \mathrm{F}_{6}\right)$.
\end{abstract}

Keywords Genetic Evaluation, Line $\times$ Tester Analysis, General Combining Ability, Specific Combining Ability

\section{Introduction}

Wheat (Triticum aestivum L.) is one of the most important food crop of the world. It is the main cereal grain crop in terms of production, nutritional value, consumption, storage qualities and trade. In Pakistan, more or less all the commercial wheat varieties developed today are pure lines (Chowdhry et al., [6].

One of the most important advances in plant improvement is the discovery of heterosis/ hybrid vigor and its utilization in breeding programs. Superiority of hybrids over pureline, mid parents and better parents is related with heterotic effects of yield contributing traits (Alghamdi [3].But efforts to evolve hybrid wheat cultivars in Pakistan are scanty (Chowdhry et al.,[6].

Improvement in wheat plant depends upon the amount of genetic variability present any other breeding method. Combining or incorporated through hybridization or GCA and SCA ability studies are frequently used by plant breeders to evaluate newly developed cultivars for their parental usefulness and to assess the gene action involved in various characters, so as to design an efficient breeding plan for further genetic upgrading of the existing material. Line $x$ tester analysis is a simple and efficient statistical approach that has been very commonly used for combining ability analysis in plant breeding.

A knowledge of general and specific combining abilities (GCA, SCA) influencing yield and its components has become increasingly important to plant breeders in the choice of suitable parents for developing potential hybrids in many crop plants (Kruvadi [14]. Assessment of GCA effects for yield components has considerable importance in selecting parents for yield improvement (Kinanci [12]. It has been further reported that number of tillers per plant and spikelets per spike were controlled by additive type of gene action (Akbar et al., [2]. Both non additive gene action (Lariket al.,[15], Süleyman and Akgüni[26] and additive gene action (Ahmadiet al.,[1], Joshi et al.,[9] has been reported for yield components in wheat.

The main objective of present study was to identify the best parents and specific combining ability of crosses for yield and its components to determine the potential of hybrid production in wheat.

\section{Materials and Methods}

The present study was carried out in the research area of Plant Breeding and Genetics, University of Agriculture, Faisalabad, under normal conditions. Lines viz., 9436, 9444 and 9452 were used as female parents while varieties viz. SH-2002, Sehar 2006 and Lasani 2008 were used as male parents and their $9 \mathrm{~F} 1$ crosses were made through manual crossing. Seeds of F1s along with their parents were sown in triplicated randomized complete block design. Spacing 
between plants and rows was maintained as 15 and $30 \mathrm{~cm}$, respectively. At maturity ten guarded plants were randomly selected from each plot and data were collected for plant height $(\mathrm{cm})$, number of tillers per plant, number of grains per spike, 1000-grain weight (g) and grain yield per plant (g).The data was subjected to analysis of variance (Steel et al., [25]. Data for the traits depicting significant difference were further analyzed by using line $x$ tester analysis (Kempthorne [10].

\section{Results and Discussions}

All genotype used as parents showed significant differences for plant height, number of tillers per plant, number of grains per spike, 1000-grain weight and grain yield per plant. All nine crosses also showed significant variation for all the traits. Variance due to Parents vs crosses was significant only for number of grains per spike and1000-grain weight. Female parents (lines) and male parents (testers)differ significantly for all the traits except for plant height in case of testers i.e. male parents. (Table $1)$.

Table 1. Analysis of variance of yield and yield components in bread wheat

\begin{tabular}{|c|c|c|c|c|c|c|}
\hline SOV & d.f & PH & T/P & G/S & TGW & GY/P \\
\hline Replications & 2 & $35.42^{\text {N.S }}$ & $0.26^{\text {N.S }}$ & $2.38^{\text {N.S }}$ & $8.54 * *$ & $0.11^{\text {N.S }}$ \\
\hline Genotypes & 14 & $58.18^{* *}$ & $10.07^{* *}$ & $90.45^{* *}$ & $100.86^{* * *}$ & $60.53^{* *}$ \\
\hline Parents & 5 & $76.89^{* *}$ & $9.92^{* *}$ & $111.43^{* *}$ & $136.34 * *$ & $72.38^{* * *}$ \\
\hline Parents vs crosses & 1 & $10.92^{\text {N.S }}$ & $0.72^{\text {N.S }}$ & $316.44^{* *}$ & $182.10^{* *}$ & $0.74^{\text {N.S }}$ \\
\hline Crosses & 8 & $52.39^{* *}$ & $11.33^{* *}$ & $49.10^{* *}$ & $68.52^{* *}$ & $60.28^{* *}$ \\
\hline Lines & 2 & $148.72^{* *}$ & $38.05^{* *}$ & $5.11^{* *}$ & $58.62^{* * *}$ & $99.95^{* *}$ \\
\hline Testers & 2 & $17.35^{\text {N.S }}$ & $3.70^{* *}$ & $114.82^{* * *}$ & $145.86 * *$ & $91.18^{* * *}$ \\
\hline LinesTesters & 4 & $21.75^{\text {N.S }}$ & $1.79^{\text {N.S }}$ & $38.23 * *$ & $34.80^{* *}$ & $25.61 * *$ \\
\hline Error & 28 & 14.87 & 0.06 & 3.88 & 1.72 & 0.38 \\
\hline
\end{tabular}

$* * * *=$ Significant at 0.1 and 0.05 alpha value respectively, ${ }^{\mathrm{NS}}=$ Non significant, $\mathrm{PH}=$ Plant height, $\mathrm{T} / \mathrm{P}=$ Number of tillers per plant, $\mathrm{G} / \mathrm{S}=$ Number of grains per spike, TGW $=1000$ grain weight, $G Y / P=$ Grain yield per plant

\subsection{General Combining Ability Studies}

Estimates of variation due to general combining ability were distributed for both male (Testers) and female (Lines) parents for the characters under study to search out the potential parents for future breeding program and the results are presented in Table 2.Regarding plant height, 9436 among female parents and SH-2002 among male parents were potential parents(desirable negative value i.e. reduction of plant height). These findings are in accordance with the results of Corral [7], Palve et al.,[20], Zubair et al.,[27] and Malik et al.,[18].

Number of tillers per plant also plays an important role in grain yield as more number of tillers are expected to results in better yielding ability. Positive GCA effects for number of tillers per plant were observed for female parents viz; 9436 and 9452 and male parent Lasani-2008. These results are in accordance with those of Qari et al.,[21], Sarkar et al. [24], Zubair et al.,[27] and Chowdhry et al.,[5].

Table 2. Estimates of general combining ability effects for yield components in three lines (female parents) and three testers (male parents) of wheat

\begin{tabular}{|c|c|c|c|c|c|}
\hline Parents & PH & T/P & G/S & TGW & GY/P \\
\hline \multicolumn{7}{|c|}{ Female Parents (lines) } \\
\hline 9436 & -4.48 & 1.23 & 0.17 & 1.75 & -2.48 \\
\hline 9444 & 3.44 & -2.37 & -0.83 & 1.17 & -1.30 \\
\hline 9452 & 1.03 & 1.15 & 0.65 & -2.93 & 3.78 \\
\hline \multicolumn{7}{|c|}{ Male Parents (Testers) } \\
\hline $\begin{array}{c}\text { Sehar } \\
2006\end{array}$ & 1.20 & -0.12 & 3.99 & 1.73 & -2.14 \\
\hline $\begin{array}{c}\text { Lasani } \\
2008\end{array}$ & 0.31 & 0.69 & -1.11 & -4.60 & -1.51 \\
\hline SH-2002 & -1.51 & -0.57 & -2.88 & 2.87 & 3.65 \\
\hline
\end{tabular}

Number of grains per spike is one of the major components of grain yield. Grains per spike shows positive association towards grain yield. Among females 9452 with (0.65) and 9436 with (0.17), among male Sehar-2006 with (3.99) were found the best general combiner parents. Similar findings have also been reported by Qari et al.,[21], Palve et al.,[20], Sarkar et al., [24] and Zubair et al.,[27]. Two female parents viz; 9436 and 9444 along with two male viz., Sehar 2006 andSH-2002 showed positive general combining ability for 1000 grain weight. These results are in agreement with the findings of Fedin et al., [8] and Zubair et al.,[27]. For grain yield per plant, one female parent and one male parent showed positive GCA effects. These results are in conformity with the findings of Khurana et al.,[11] and Sarkar et al.,[24]. These parents could be used for genetic improvement of respective yield component.

\subsection{Specific Combining Ability Studies}

Results for specific combining ability effects of various yield related characters are presented in Table 3 .

$9436 \times$ SH-2002 (-3.07), $9444 \times$ Sehar 2006 (-1.99), 9444 $\times$ Lasani $2008(-1.04)$ and $9452 \times$ Sehar $2006(-0.02)$ showed desirable negative specific combining ability effects for plant height (Liu et al., [16] and Rajara and Maheshwari [22]. Maximum positive specific combining ability effects were found in the crosses viz., $9436 \times$ Sehar 2006, 9452× SH-2002, $9452 \times$ Lasani 2008 and $9444 \times$ SH-2002(Sarkar et al. [24], Majumdar and Bhowal [17] and Chowdhry et al. [5]. For number of grains per spike, about $55 \%$ crosses showed positive specific combining ability. These crosses were $9444 \times$ SH-2002, $9436 \times$ Sehar 2006, $9452 \times$ Lasani 
2008, $9436 \times$ Lasani 2008 and $9452 \times$ SH-2002 (Kraljevic-Balalic et al.[13], Rasal et al.[23] and Chandrakar et al. [4]. For 1000-grain weight, highest positive SCA effects were recorded in 3 out of 9 crosses. The best specific combiner were found to be $9452 \times$ SH-2002 and $9436 \times$ Lasani 2008 possessing values 3.73 and 2.69 respectively(Sarkar et al. [24] and Chowdhry et al.[5]. SCA effects were found much variable among crosses for grain yield per plant.9436 × SH-2002 (2.75) exhibited the highest positive SCA effects for grain yield per plant (Corral [7], Khurana et al. [11], Mishra et al. [19] and Chowdhry et al. [5].

Table 3. Estimates of specific combining ability for yield components of wheat crosses through line $\times$ tester analysis

\begin{tabular}{|c|c|c|c|c|c|}
\hline Crosses & PH & T/P & G/S & TGW & GY/P \\
\hline $1.9436 \times$ Sehar 2006 & 2.02 & 0.85 & 3.25 & -1.51 & -1.68 \\
\hline $2.9436 \times$ Lasani 2008 & 1.04 & -0.09 & 0.89 & 2.69 & -1.07 \\
\hline $3.9436 \times$ SH-2002 & -3.07 & -0.76 & -4.14 & -1.18 & 2.75 \\
\hline $4.9444 \times$ Sehar 2006 & -1.99 & -0.05 & -1.22 & 2.65 & -0.17 \\
\hline $5.9444 \times$ Lasani 2008 & -1.04 & -0.16 & -2.04 & -0.09 & -0.80 \\
\hline $6.9444 \times$ SH-2002 & 3.04 & 0.21 & 3.26 & -2.55 & 0.97 \\
\hline $7.9452 \times$ Sehar 2006 & -0.02 & -0.80 & -2.03 & -1.14 & 1.85 \\
\hline $8.9452 \times$ Lasani 2008 & 0.07 & 0.25 & 1.15 & -2.59 & 1.87 \\
\hline $9.9452 \times$ SH-2002 & 0.02 & 0.55 & 0.88 & 3.73 & -3.73 \\
\hline
\end{tabular}

\section{Conclusion}

Considerable genetic variation exists in wheat genotypes for improving basic yield components. Both additive and non additive gene action governs expression of quantitative yield traits. Selection for parents with high GCA effects and crosses with high SCA effects would be a suitable strategy for yield improvement in wheat.

\section{REFERENCES}

[1] Ahmadi, J., A.A. Zali, B.Y. Samadi, A. Talaie, M.R. Channadha and A. Saeidi:(2003)A study of combining ability and gene effect in bread wheat under drought stress conditions by diallel method. Iranian J. Agric. Sci. 34: 1-8.

[2] Akbar, M., A. Rehman, M.H. Chaudhry and M. Hussain:(1997) Prepotency judgment diallel crosses in $F_{1}$ generation for wheat improvement. Sci. Int. (Lahore). p. 303-305.

[3] Alghamdi, S.S., 2009. Heterosis and combining ability in a diallel cross of eight faba bean (ViciafabaL.) genotypes. Asian J. Crop Sci., 1: 66-76.

[4] Chandrakar, P.K., R.K. Mishra and V.M. kohli:(1994)
Combining ability analysis in wheat (Triticum aestivum L.) under late sown conditions. Adv. Pl. Sci. 7(2): 382-388.

[5] Chowdhry, M.A., G. Rabbani, G. M. Subhani and I. Khaliq:(1999) Combining ability studies for some poly genic traits in aestivum species. Pak. J. Biol. Sci., 2(2): 434-437.

[6] Chowdhry, M.A., N. Parveen, I. Khaliq and M. Kashif:(2005) Estimation of heterosis for yield and yield components in bread wheat. J. Agric. Soc. Sci., 1: 304-308.

[7] Corral, L.R.:(1983) Influence of competition on combining ability estimates and subsequent prediction of progeny performance in wheat (Triticum aestivum L. em. Thell). Ph.D. Thesis. Oregon State University, Oregon.

[8] Fedin, M.A., D.Y. Silis, T.V. Shmakava and E.N. Mironov:(1983) Combining ability of some winter wheat varieties. Vestnik Selskokhozyaistvennai Nauki, USSR. 2: 47-52.

[9] Joshi, S.K., S.N. Sharma, D.L. Singhania and R.S. Sain:(2003) Genetic analysis of yield and its component traits in spring wheat (Triticum aestivum L.). Acta Agron. Hungarica. 51(2): 139-147.

[10] Kempthrone, O: (1957)An introduction to genetic statistics. John Wiley and Sons, Inc., New York.

[11] Khurana, V., R.K. Singh, G. Munjal and V.P. Singh:(1983) Combining ability of brown-rust resistance stocks of wheat for yield attributes. Indian J. Genet. Plant Breed., 43: 106-108

[12] Kinaci, G: (1996) Orta Anadolu için Line X Tester Yöntemiyle Süne Zararından Az Etkilenen Verimli ve Kaliteli Ekmek Bugday Çesitleri Islahı Üzerine Bir Arastırma. S.Ü. Zir. Fak. Der. 9(11): 181-187.

[13] Kraljevic-Balalic, M., S. Petrovic and P. Roncevic:(1991) Line $\mathrm{x}$ tester analysis for yield components in spring wheat. Res. Inst. Agroecology and soil management. 147-153. [Wheat, Barley and Triticale Absts. 10(6): 5053; 1993.

[14] Kruvadi, S:(1991)Diallel analysis and heterosis for yield and associated characters in durum wheat under upland conditions. Turrialba Publ. Canada, 41(3): 335-338.

[15] Larik, A.S; A. R Mahar and H. M. I. Hafiz: (1995) Heterosis and combining ability estimates in diallel crosses of si cultivars of spring wheat. Wheat Information Service. 34: 12-19.

[16] Liu, G.T., J.B. Zhu, S. Z. Zhang:(1989) Studies on quality and agronomic characters in Triticum aestivumL. I. Heterosis and Combining ability. Acta. Agric. Univ. Pekinensis 15(3): 259-266. [P1. Br. Absts. 60(8): 7349; 1990].

[17] Majumdar, P.K. and J.G. Bhowal:(1988) Combining ability in a few varieties of $\mathrm{T}$. aestivum, $\mathrm{T}$. compactum and $\mathrm{T}$. sphaerococcum. Indian J. Gen. \& Pl. Br. 48(1): $43-48$ [Pl. Br. Absts. 60(5): 4020; 1990].

[18] Malik, M.F.A., S.I. Awan and S. Ali:(2005) Genetic behavior and analysis of quantitative traits in five wheat genotypes. J. Agric. Soc. Sci., 01(4): 313-315.

[19] Mishra, P.C., T.B. singh and D.P. Nema:(1994) Combining ability analysis of grain yield and some of its attributes in bread wheat under late sown conditions. Crop Res. 7(3): 413-423. 
[20] Palve, S.M., R.Y. Thete and A.D. Dumbre:(1987) Combining ability in wheat from line $\times$ tester analysis. Maharashtra Agric. Univ. J., 12: 244-245.

[21] Qari, M.S., N. Khan and A.G. Khan:(1984) Combining ability analysis for yield and yield components of spring wheat diallel crosses. J. Agric.Res., 22(2): 95-99.

[22] Rajara, M.P. and R.V. Maheshwari: (1996) Combining ability in wheat line $\mathrm{x}$ tester analysis. Madras Agric. J. 83(2): 107-110. [P1. Br. Absts. 67(4):3334; 1997].

[23] Rasal, P.N., H.S. Patil, V.W. Chavan and B.S. Manake:(1991) Combining ability studies for certain quantitative traits in wheat. J. Maharashtra Agric. Univ. 16(2): 206-208.
[24] Sarkar, D.D., O.J. Joardar and M. Hussain:(1987) Combining ability analysis in wheat. Environ. Ecol., 5: 809-810

[25] Steel, R.G.D., Torrie, J.H. and D.A. Dickey:(1997) Principles and Procedures of Statistics. A Biometrical Approach. McGraw Hill, Book Inc., New York, USA.

[26] Süleyman, S. and N. Akgüni:(2007) Combining ability and inheritance of some agronomical traits in bread wheat (Triticum aestivum L.). Ziraat Fakültesi Dergisi. 21(41): 104-108.

[27] Zubair, M., A.R. Chowdhry, I.A. Khan and A. Bakhsh:(1987) Combining ability studies in bread wheat (Triticum aestivum L.). Pakistan J. Bot., 19: 75-80. 